\title{
Breaking force analysis of cotton ring-spun yarns
}

\author{
DOI: 10.35530/IT.071.03.1650
}

\section{ABSTRACT - REZUMAT}

\section{Breaking force analysis of cotton ring-spun yarns}

The most important factor influencing the production efficiency of final textile products made from yarns as well as the product performance are the tensile properties of the yarn. The breaking force of spun yarns, assessed with standard static procedure, depends on several parameters, one of them being the testing conditions. In our research, the effect of testing conditions (climatic conditions, the ratio gauge length/constant rate of extension and sampling, which refers to the number of yarn package and the position of package winding, taken from the bobbin) on the breaking force of $100 \%$ cotton ring-spun yarns was analyzed using the statistical evaluation method "ANOVA". The results clearly indicate that indeed all input parameters of testing conditions have a statistically significant effect on the breaking force of the yarn. When we judge the suitability of yarns to withstand a certain tension produced by technological procedures, not only average breaking force should be focused on. The information regarding the tested minimum breaking force of yarn becomes very important regarding our decision whether yarn fulfills the prescribed value of breaking force.

Keywords: ring-spun yarns, breaking force, testing conditions

\section{Analiza privind rezistența la rupere a firelor din bumbac filate cu inele}

Cel mai important factor care influențează eficiența producției de produse textile finale obținute din fire, precum și performanța produsului este reprezentat de proprietățile de tracțiune ale firelor. Rezistența la rupere a firelor filate, evaluată cu procedura statică standard, depinde de mai mulți parametri, unul dintre aceștia fiind condițiile de testare. În această lucrare a fost analizată, folosind metoda de evaluare statistică „ANOVA”, influența condițiilor de testare (condițiile climatice, raportul dintre distanța între cleme și viteza constantă a alungirii epruvetei și eșantionarea, care se referă la numărul de formate de fire și poziția înfășurării firelor, preluate din bobină), asupra rezistenței la rupere a firelor filate cu inele, din 100\% fibre de bumbac. Rezultatele au indicat clar că, într-adevăr, toți parametrii de intrare ai condițiilor de testare au un efect semnificativ statistic asupra rezistenței la rupere a firului. Atunci când se evaluează capacitatea firelor de a rezista la o anumită solicitare produsă în timpul proceselor tehnologice, nu trebuie să se țină cont numai de forța de rupere medie. Informațiile privind forța de rupere minimă obținută la testarea firelor devin foarte importante pentru a decide dacă firul corespunde valorii impuse pentru rezistența la rupere.

Cuvinte-cheie: fire filate cu inele, rezistență la rupere, condiții de testare

\section{INTRODUCTION}

The tensile properties of spun yarns are one of the basic performance properties of a product and as such, are important not just in the case of post spinning mechanical operations (like warping, weaving, braiding, knitting, production of direct oriented structures and composites), but also in operations needed to assemble the yarns into a final product. For example, spun yarns are used in the production of women's tampons, where inappropriate or insufficient yarn tensile strength can lead to the breaking of yarns, and consequently, to a lower efficiency of production. Tensile properties are characterized by two parameters: a) breaking tenacity, which is a ratio between breaking load and yarn linear density, expressed in N/tex, and b) breaking strain, which is a ratio between breaking extension and initial length of yarn, expressed in \% [1]. Breaking strength could be also expressed as absolute value, e.g. as breaking force, which is the maximum force applied to the testing yarn in a tensile test carried to rupture, expressed in $\mathrm{cN}$ or $\mathrm{N}$. There are several factors, which have an impact on the tensile properties of spun yarn. These can be grouped into the following categories: a) properties of spinning material (tensile strength of used fibers, fiber length, fiber cross-section etc.); b) yarn structure (arrangement of fibers in the yarn, yarn fineness, the number of fibers in yarn cross-section, adhesion, twist, type of spinning technologies, yarn irregularities); c) testing conditions (gauge length, rate of extension/loading, humidity, temperature, the manner of sampling).

In a standard test procedure, a gauge length of 500 $\mathrm{mm}$ is employed, whilst having $20 \pm 2 \mathrm{~s}$ of time available in order to cause breaking. A clamped yarn breaks in its weakest point according to the principle of the "weakest link" and this strength value is then assigned to the whole length of yarn [2]. As the test sample is gripped at the two ends and maintains such a static state during the duration of the testing process, the evaluated tensile properties are treated as static tensile properties [3]. It is worth mentioning that in actual practice the yarns undergo stress and strains that are substantially different from those 


\begin{tabular}{|l|c|}
\hline \multicolumn{2}{|c|}{ TEST OF NULL HYPOTHESES } \\
\hline \multicolumn{1}{|c|}{ Null hypotheses $-\mathbf{H}_{0}$} & Confirmation of $\mathbf{H}_{0}$ \\
\hline Climatic conditions don't have an effect on yarn braking strength & no \\
\hline Gauge length/rate of extension doesn't have an effect on yarn breaking strength & no \\
\hline Number of the package doesn't have an effect on yarn breaking strength & no \\
\hline The position of package winding doesn't have an effect on yarn breaking strength & \\
\hline
\end{tabular}

applied in standard testing conditions. Therefore, the results obtained under a standard test method cannot always be expected to fully reflect the end-use performance of the yarns [4]. The tensile strength and breaking extension of the yarns are not unique functions, but they are dependent upon the rate of extension and gauge length. To compare tensile properties of yarns, it is thus important to indicate if the tester uses a constant rate of loading (CRL) or a constant rate of extension (CRE) [5], and what is the distance between gauges. The results of some researches indicate the following:

- yarn tenacity increases with the extension rate for all spinning system [4] and that the relationship between yarn tenacity and the logarithm of rate of extension is approximately linear [6]; the effect of rate of extension on breaking extension is lesser than its effect on strength [7];

- yarn tenacity decreases with higher gauge length for ring and friction spinning systems; the strength of ring- and friction-spun yarns show a sharp drop, as the gauge length increases from $1 \mathrm{~mm}$ to $40 \mathrm{~mm}$ and from $1 \mathrm{~mm}$ to $20 \mathrm{~mm}$, respectively; as for gauge length greater than $40 \mathrm{~mm}$, the strength of ringspun yarns appears fairly constant, whereas the strength of friction-spun yarns is reduced continuously with the increase of gauge length [8].

In this work, the influence of testing conditions (climatic conditions, gauge length/rate of extension, the number of package, the position of package winding taken from the bobbin) on the breaking force of ringspun yarns produced from cotton fibers have been analyzed. The ANOVA statistical method has been used to assess the significance of the individual parameter.

\section{MATERIALS AND METHODS}

Carded, bleached and hydrophobic (Sevophob) $100 \%$ cotton ring-spun yarns used for the production of women's tampons were analyzed in this research. The fineness of used yarns was $60 \times 4$ tex. Breaking force was measured according to the ISO 2062 from the same yarn lot using Tinius Olsen universal tester (Model H1OKT) under following testing conditions:

- climatic conditions: standard $(65 \pm 2 \%$ relative humidity; $\left.20 \pm 2^{\circ} \mathrm{C}\right)$ and non-standard conditions $(40 \pm 2 \%$ relative humidity; $23 \pm 2^{\circ} \mathrm{C}$ );

- gauge length - constant rate of extension: $200 \mathrm{~mm}$ - $100 \mathrm{~mm} / \mathrm{min} ; 250 \mathrm{~mm}-250 \mathrm{~mm} / \mathrm{min}$, and 500 $\mathrm{mm}-500 \mathrm{~mm} / \mathrm{min}$;
- number of the package: No. 1, No. 2, and No. 3;

- position of package winding taken from the bobbin: outer, middle, and inner winding;

- number of measurements per sample: 60 .

Altogether $3240(60 \times 2 \times 3 \times 3 \times 3)$ tests were conducted to determine the mean value of breaking force and elongation of tested spun yarns. To determine if there was any difference among the testing conditions according to the breaking force of spun yarns and to test null hypotheses (table 1), analysis of variance procedure (ANOVA) was performed using IBM SPSS 22 statistical software package. The selected value of significance level for this procedure was 0.05 (or $95 \%$ confidence level).

\section{RESULTS AND DISCUSSIONS}

The results of ANOVA analysis are presented in table 1. The input parameters (climatic conditions, gauge length/rate of extension, the number of the package and the position of package winding taken from the bobbin) with $p$-values lower than 0.05 are expected to be significant. Since the results showed that all input parameters had $p$-value lower than 0.05 , all null hypotheses were rejected. This means that testing conditions significantly affect the yarn breaking force at $95 \%$ of confidence level.

\section{The effect of climatic conditions}

Figure 1 shows the results of breaking force of cotton yarns regarding the standard and non-standard climatic conditions at different positions of package winding. The breaking force measured by standard climatic conditions is higher than by non-standard climatic conditions. Cotton yarns absorb more water vapour at higher relative humidity, thus resulting in

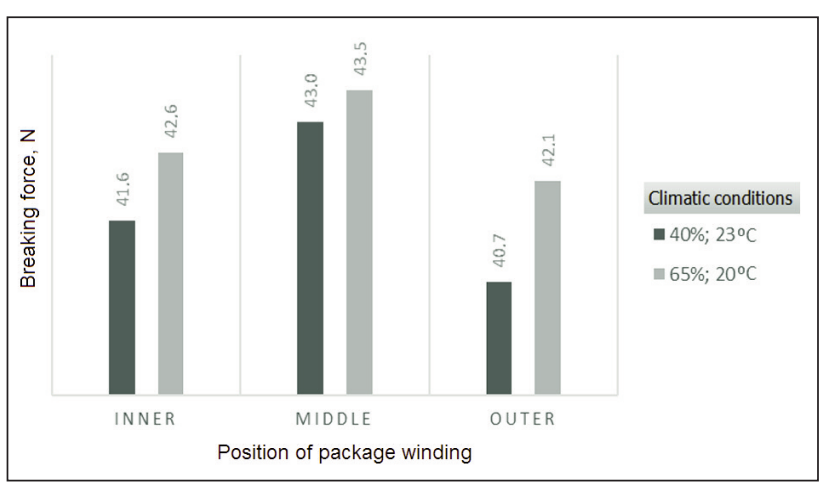

Fig. 1. The effect of climatic conditions on yarn breaking force 
higher breaking strength. This is valid for all positions of package windings.

\section{The effect of gauge length/rate of extension}

Figure 2 shows the results of breaking force of cotton yarns regarding the gauge length - GL/constant rate of extension - CRE at different number of the package.

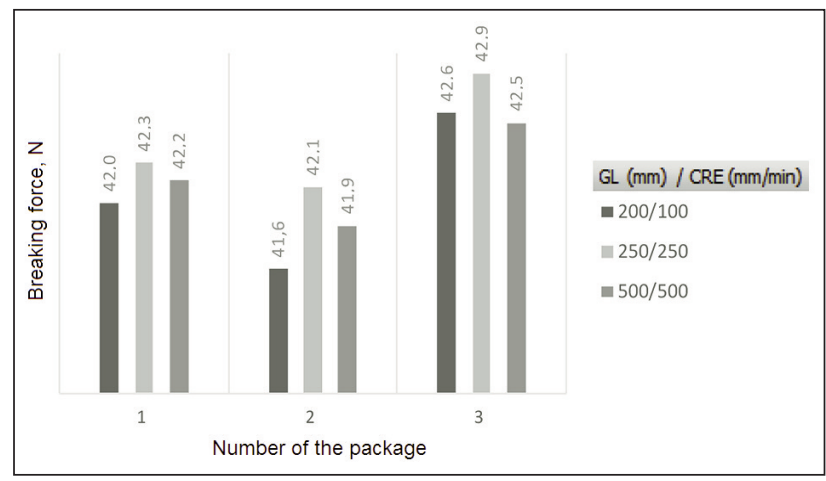

Fig. 2. The effect of gauge length/rate of extension on yarn breaking force

We should have in mind that the rate of extension was not the same during the increase of gauge length from $200 \mathrm{~mm}$ to $500 \mathrm{~mm}$. The ratio between the gauge length and the constant rate of extension was 2, 1 and 1 for 200, 250 and $500 \mathrm{~mm}$ of gauge length, respectively (table 2 ).

Table 2

\begin{tabular}{|c|c|c|}
\hline \multicolumn{2}{|c|}{ GAUGE LENGTH AND RATE OF EXTENSION RATIO } \\
\hline $\begin{array}{c}\text { Gauge length - } \\
\text { GL (mm) / constant } \\
\text { rate of extension - } \\
\text { CRE (mm/min) }\end{array}$ & $\begin{array}{c}\text { Ratio } \\
\text { GL/CRE }\end{array}$ & $\begin{array}{c}\text { Ratio } \\
\text { CRE/GL }\end{array}$ \\
\hline $200 / 100$ & 2 & 0.5 \\
\hline $250 / 250$ & 1 & 1 \\
\hline $500 / 500$ & 1 & 1 \\
\hline
\end{tabular}

If we compare the results of breaking force for yarns with the same ratio between the gauge length and rate of extension, this following conclusion can be made: yarn breaking force decreases with higher gauge length (from 250 to 500). At higher gauge lengths, there is more slippage and breakage of fibers compared to shorter gauge lengths. If we observe the ratio between the constant rate of extension and gauge length, we can conclude that these ratios were $0.5,1$ and 1 for 200,250 and $500 \mathrm{~mm}$ of gauge length, respectively. If we compare the results of breaking force for yarns with an increasing ratio between the constant rate of extension and gauge length, this following conclusion can be made: yarn breaking force increases with increasing constant rate of extension per gauge length. This is valid mostly for all numbers of the yarn package. As the rate of extension increases, the percentage of ruptured fibres increases (the inter-fibre pressure tends to increase), resulting in a higher breaking force, while greater numbers of fibres are contributing to the breaking load.

\section{The effect of sampling}

According to the standard, sampling should be performed according to the procedures; namely if only mean values are required, then 10 packages shall be taken from the bulk sample, distributed as evenly as possible among the cases and among the levels in each case. In our case, 3 bobbins (packages) were taken from the testing material, marked as package 1 , package 2 and package 3 . Then, from each package, the appropriate lengths of yarn were taken at three different positions of package winding, namely: from the outer, middle and inner package winding. From each package winding position, 60 specimens were tested. Figures 3 and 4 show the results of breaking force of cotton yarns in regards to the number of package and the position of package winding taken from the bobbin (outer, middle, and inner winding) at different climatic conditions, respectively.

From the figure 3 , the differences between the packages can be seen, which are according to the ANOVA analysis, statistically important.

Results show that the middle package winding has the highest breaking force in comparison with the outer and inner package winding, thus implying that yarn structure in the middle of the bobbin is more homogenous, with less weak points. We assume that in this case the tension at winding was not kept at the

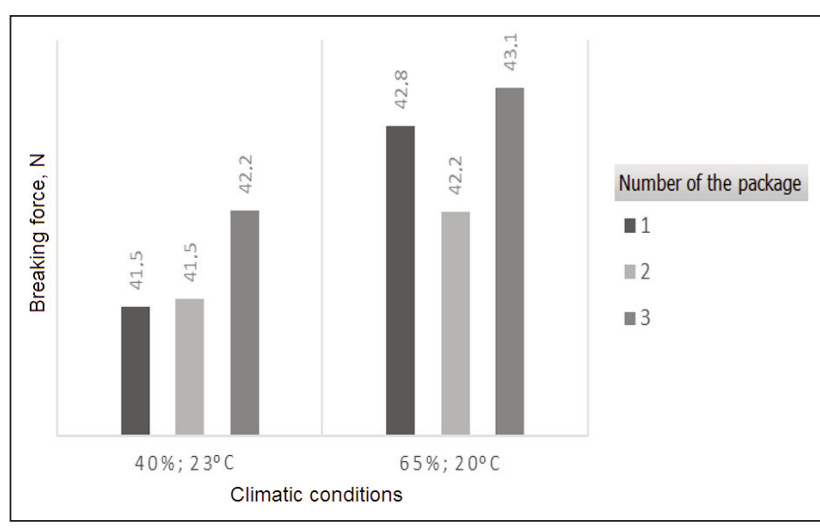

Fig. 3. The effect of the number of yarn package on yarn breaking force

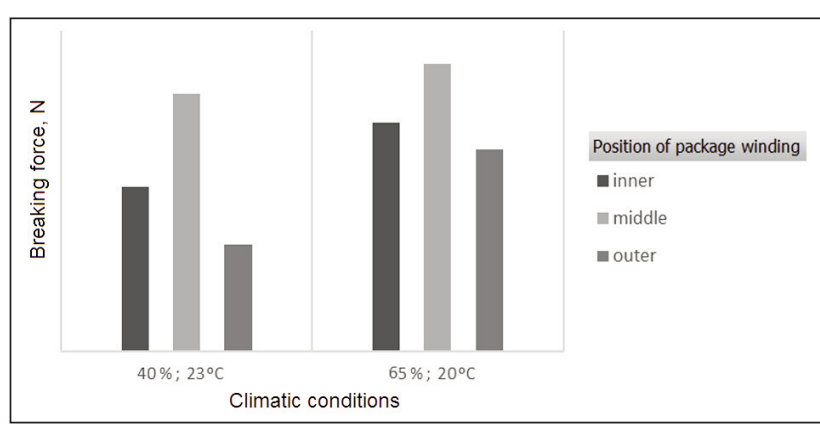

Fig. 4. The effect of the position of package winding on yarn breaking force 
same level with the increase of bobbin diameter, thus resulting in different yarn breaking strength. Yarn damage is highest at yarn taken from the outer package winding.

\section{CONCLUSIONS}

The breaking strength of spun yarns is essential during the production of the final product. Consequently, it is important to use those yarns, which will be able to maintain tension produced by technological processes. There are several factors influencing the breaking strength of yarns; one of them is testing conditions. In our research, the testing conditions, namely climatic conditions, the gauge length/constant rate of extension, the number of bobbin (package), the position of package winding taken from the bobbin, were analyzed using standard static test procedure and statistical evaluation of the results (ANOVA analysis). The results clearly indicate that all input parameters of testing conditions have a statistically significant effect on the yarn breaking force (95\% confidence level). This implies that even if the declared breaking force of spun yarns is achieved (assessed with standard test procedure), the results cannot be taken as reliable in actual practice, as they are dependent upon our subjective decision - which package we will take from the lot and how evenly we will take the yarn from the packages. For the producers of the final product, the information regarding the tested minimum breaking strength of yarns is more appropriate in comparison to mean breaking strength, when we judge the suitability of yarn to withstand a certain tension produced by technological procedures.

\section{ACKNOWLEDGEMENT}

The author acknowledges the financial support from the Slovenian Research Agency (research core funding No. P2-0063).

\section{REFERENCES}

[1] Ghosh, A., Majumdar, A., Characterizing the Tensile Properties of Spun Yarns Using Bivariate Normal Distribution. In: Fibers and Polymers, 2010, 11, 4, 642-647

[2] Lizàk, P., Yarn Strength Dependence on Test Length, In: Fibers \& Textiles in Eastern Europe, 2002, 38, 3, 32-34

[3] Das, B.R., Ishtiaque, S.M., Rengasamy, R.S., Study on the Static and Dynamic Strength and Weavability of Spun Yarns, In: Fibers and Polymers, 2012, 13, 2, 231-236

[4] Ghosh, A., Ishtiaque, S.M., Rengasamy, R.S., Analysis of Spun Yarn Failure. Part I: Tensile Failure of yarns as a Function of Structure and Testing Parameters, In: Textile Research Journal, 2005, 75, 10, 731-740

[5] Das, B.R., Tensile Behavior of Spun Yarns under Static State, In: Journal of Engineered Fibers and Fabrics, 2010 , $5,1,1-9$

[6] Meredith, R., The Effects of Rate of Extension on the Tensile Behavior of Viscose and Acetate Rayons, Silk and Nylon, In: Journal of the Textile Institute, 1954, 26, 4, 354-357

[7] Majumdar, A., Assessment of Tensile Properties of Cotton Yarns, In: Indian Journal of Fiber \& Textile Research, 2001, 11, 4, 642-647

[8] Oxenham, W., Zhu, R.Y., Leaf, G.A.V., Observation on the Tensile Properties of Friction-Spun Yarns, In: Journal of the Textile Institute, 1992, 83, 4, 621-623

\section{Author:}

\section{POLONA DOBNIK DUBROVSKI}

University of Maribor, Faculty of Mechanical Engineering, Textile Materials and Design Department, Smetanova ulica 17, 2000, Maribor, Slovenia

Corresponding author:

POLONA DOBNIK DUBROVSKI

e-mail: polona.dubrovski@um.si 